\title{
Comparative Analysis of Chemical, Physical and Biological Contaminants in Drinking Water in Various Developed Countries around the World
}

\author{
Kaleh Karim ${ }^{1,2}$, Sujata Guha1, Ryan Beni ${ }^{1 *}$ \\ ${ }^{1}$ Department of Chemistry, Tennessee State University, Nashville, TN, USA \\ ${ }^{2}$ Department of Biological Sciences, Tennessee State University, Nashville, TN, USA \\ Email: ^rbeni@tnstate.edu
}

How to cite this paper: Karim, K., Guha, S. and Beni, R. (2020) Comparative Analysis of Chemical, Physical and Biological Contaminants in Drinking Water in Various Developed Countries around the World. Journal of Water Resource and Protection, 12, 714-728.

https://doi.org/10.4236/jwarp.2020.128043

Received: May 20, 2020

Accepted: August 16, 2020

Published: August 19, 2020

Copyright $\odot 2020$ by author(s) and Scientific Research Publishing Inc. This work is licensed under the Creative Commons Attribution International License (CC BY 4.0).

http://creativecommons.org/licenses/by/4.0/

\begin{abstract}
Sustaining a reliable and contaminant-free drinking water is becoming an increasing challenge worldwide due to human activity, industrial waste, and agricultural overuse. Surface water is the main source of drinking water around the world. However, groundwater is also becoming increasingly popular, due to its clarity and minimal need for processing to reduce turbidity. Over the years, the demand and growth in the agricultural industry has also been the means of groundwater contamination. Due to the health burden that raw water can pose, water must be processed and purified prior to consumption. Raw water quality can be compromised by physical, chemical (heavy metals and disinfection by-products), and biological contaminants. Biological contaminants can significantly impact immunocompromised populations, while chemical contaminants can impact the growth and development of young children. Although obtaining a steady and high-quality water flow to the general population is an increasing challenge, developed countries have utilized state-of-the-art technologies and techniques to provide contaminantfree water to their citizens. This research aims to provide information about the regulatory parameters, characteristics, and sources of safe drinking water in the world as a model for future use in the developing world. In this, secondary data was used to compare and contrast drinking water quality among countries in the European Union, the United States, Canada, the United Kingdom, Singapore, New Zealand, Australia, Qatar, and the United Arab Emirates. The data indicates that Ireland and the United Kingdom have relatively lower amounts of contaminants in their drinking water. Upon completing this research, it is recommended that countries desiring clean drinking water systems should initiate and invest in programs that control and protect treatment plants, water distribution systems, water sources, and catchments.
\end{abstract}




\section{Keywords}

Potable Water, Water Contaminants, Drinking Water, Lead, Turbidity, Water Quality, Heavy Metals, Disinfection By-Products, Water Sources

\section{Introduction}

Water is the most precious commodity for humans. However, obtaining clean drinking water has become an increasing challenge for many around the globe, especially for developing and underdeveloped countries. Water pollution, due to human activity and poor industrial waste management, has exasperated poor water quality. Environmentalists and public health professionals face challenges in their battle against the exposure to infectious agents via drinking water in developing countries, where millions of people consume water that is contaminated with fecal matter. After the implementation of the water chlorination process in 1897 in Maidstone, England to eradicate waterborne pathogens, many developed countries followed suit and significantly reduced outbreaks due to the waterborne pathogens [1] [2]. Although the chlorination has remained unchanged but effective over the past century, studies indicate that elevated chlorine by-products can increase risk of miscarriages [3] [4], infertility [5], and even cancer [6] [7] [8]. In addition to biological contaminants, chemical, physical, and radiological contaminants are also present and can compromise drinking water quality. The World Health Organization (WHO) has implemented guidelines to mitigate the health burden associated with the consumption of water contaminated with various agents. It is ultimately the obligation of each nation to ensure the availability of infrastructure to distribute high quality water to its citizens. In addition, each country must set guidelines to ensure that the standards are appropriate and unique to the needs of their nation, depending on the drinking water source.

The European countries adhere to the standards set by the European Union. In the United States, the Environmental Protection Agency (EPA) determines strict guidelines to ensure that drinking water quality surpass standards [9] [10]. The drinking water standards set by the EPA are implemented by every public water system (PWS) in the United States. Other developed countries have set regulations modeled after the standards set by the WHO, as seen in Table 1 .

It is noteworthy that the United Arab Emirates has the lowest allowable levels of chlorine in their drinking water (Table 1), perhaps due to the fact that their drinking water comes from desalination plants derived from sea water. The majority of the countries examined in this study obtain their drinking water from surface water, as shown in Table 2 and Figure 1. In the United Arab Emirates, groundwater is reserved for agricultural use and drinking water is mainly derived from seawater [11]; hence, well water is not regulated. However, private wells are the main source of drinking water in rural communities in the United 
Table 1. Limits of contaminants listed in the Drinking Water Regulations for the various developed countries.

\begin{tabular}{|c|c|c|c|c|c|c|c|}
\hline \multirow{2}{*}{$\begin{array}{c}\text { Countries/ } \\
\text { Regulatory Agencies }\end{array}$} & \multicolumn{2}{|c|}{ Regulated Chemicals } & \multicolumn{2}{|c|}{ Secondary-Regulated Chemicals } & \multicolumn{2}{|c|}{ Physical } & \multirow{2}{*}{$\begin{array}{c}\text { Biological } \\
\text { Total Coliform } \\
(\mathrm{cfu} / 100 \mathrm{~mL})\end{array}$} \\
\hline & $\begin{array}{l}\text { Lead } \\
(\mathrm{mg} / \mathrm{L})\end{array}$ & $\begin{array}{l}\text { Copper } \\
(\mathrm{mg} / \mathrm{L})\end{array}$ & $\begin{array}{l}\text { Chlorine } \\
(\mathrm{mg} / \mathrm{L})\end{array}$ & $\begin{array}{l}\text { Total Trihalomethane } \\
\qquad(\mathrm{mg} / \mathrm{L})\end{array}$ & $\begin{array}{l}\text { Turbidity } \\
\text { (NTU) }\end{array}$ & $\mathrm{pH}$ & \\
\hline World Health Organization (WHO) & 0.01 & 2 & 5 & 1 & 5 & No guideline & $<1$ \\
\hline $\begin{array}{c}\text { United States } \\
\text { (Environmental Protection Agency) }\end{array}$ & 0.015 & 1.3 & $0.2-4$ & 0.08 & 5 & $6.5-8.5$ & $<5 \%$ per month \\
\hline $\begin{array}{c}\text { European Union } \\
\text { (EU Drinking Water Directive) }\end{array}$ & 0.01 & 2 & No guideline & 0.1 & 4 & no guideline & 0 \\
\hline $\begin{array}{c}\text { United Kingdom } \\
\text { (Drinking Water Inspectorate) }\end{array}$ & 0.01 & 2 & No guideline & 0.1 & 4 & $6.5-9.5$ & 0 \\
\hline Canada (Health Canada) & 0.005 & 2 & 2 & 0.1 & 0.3 & $6.5-8.5$ & 0 \\
\hline $\begin{array}{c}\text { Singapore (PUB Singapore's National } \\
\text { Water Agency) }\end{array}$ & 0.01 & 2 & 5 & $1 / 0.56$ & 5 & $6.5-9.5$ & $<1$ \\
\hline $\begin{array}{l}\text { Ireland (Ireland's } \\
\text { Environmental Protection agency) }\end{array}$ & 0.01 & 2 & No guideline & 0.1 & 1 & No guideline & 0 \\
\hline New Zealand (NZ Ministry of Health) & 0.01 & 1.3 & 5 & $1 / 0.71$ & 2.5 & $7.0-8.5$ & $<1$ \\
\hline Germany (Federal Ministry of Health) & 0.01 & 2 & 5 & 0.1 & 1 & $6.5-9.5$ & 0 \\
\hline $\begin{array}{c}\text { Iceland (Environmental Protection } \\
\text { Agency of Ireland) }\end{array}$ & 0.01 & 2 & No guideline & 0.1 & 5 & $6.5-9.5$ & 0 \\
\hline $\begin{array}{c}\text { Australia (National Health and Medical } \\
\text { Research Council) }\end{array}$ & 0.01 & 1 & 5 & 0.25 & 5 & $6.5-8.5$ & $<2$ \\
\hline $\begin{array}{l}\text { United Arab Emirates (Environment } \\
\text { Agency Abu Dhabi) }\end{array}$ & 0.01 & 2 & $0.2-0.5$ & $1 / 0.56$ & 4 & $7-9.2$ & 0 \\
\hline $\begin{array}{c}\text { Qatar (Qatar Electricity and Water } \\
\text { Corporation) }\end{array}$ & 0.01 & 2 & 5 & $1 / 0.56$ & 4 & $6.5-8$ & 0 \\
\hline
\end{tabular}

Table 2. Drinking water sources for capital cities in various countries.

\begin{tabular}{cc}
\hline Country/Capital & Drinking Water Source \\
\hline Australia/Canberra & Lake Burragorang \\
Canada/Ottawa & Ottawa River \\
Germany/Berlin & Mügglesee and Tegeler See groundwater \\
Iceland/Reykjavík & Catchments in Heiômörk, Berjadalur, Akrafjall and Fossamelar \\
Ireland/Dublin & Poulaphuca Lake \\
New Zealand/Wellington & Hutt River, Wainuiomata River and Orongorongo River \\
Qatar/Doha & Persian Gulf \\
Singapore/Singapore & MacRitchie Reservoir \\
UAE/Abu Dhabi & Persian Gulf \\
United Kingdom/London & River Thames and River Lee \\
USA/Washington, DC & Potomac River \\
\hline
\end{tabular}

States. Yet private wells are not regulated by the federal government under the Safe Drinking Water Act [12], leaving about forty million individuals vulnerable 


\section{Water Source Distribution}

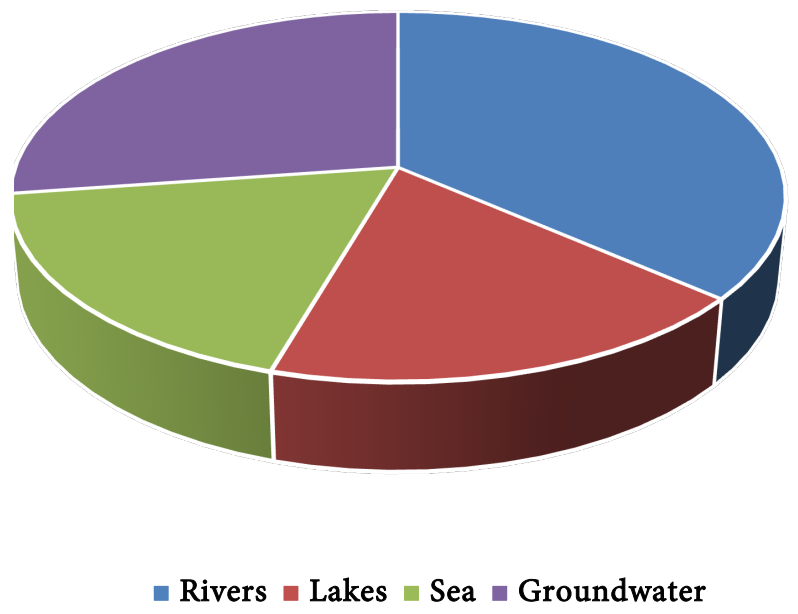

Figure 1. Water source distribution, indicating that majority of countries use surface water as their primary source of drinking water.

to the possible consequences of consuming contaminated water [13]. Inadequacy in the justice system could leave hundreds of rural communities vulnerable to the drinking water contaminants and their modest socioeconomic background dictate their inability to mitigate the health risks [14]. This inadequacy in social justice is a challenge throughout the globe.

Regulated public water can be contaminated with heavy metals, such as lead, copper, as well as physical (turbidity) and microbiological agents (E. coli, cryptosporidium, etc.) in the United States, European countries, Qatar, United Arab Emirates, and other countries around the globe. Lead and copper are a growing issue for countries with older and deteriorating public water infrastructure. Poor countries that rely on surface water, where water does not run through public pipes and is rather taken out directly from the source, do not have challenges posed by heavy metals. Rather, they suffer from turbidity (measure of water cloudiness and the main source of physical contaminant in raw water) and total coliform (group of bacteria found in the digestive system of warm-blooded animals).

Turbidity is a result of invisible particles measured in nephelometric turbidity units (NTU). The United States EPA and the WHO standards require turbidity to remain below $5 \mathrm{NTU}$, while the European standards limit turbidity to 4 NTU. Other countries, such as Ireland, Qatar, New Zealand, Australia, and the United Arab Emirates, have regulations that are significantly lower, as shown in Table 1 [15] [16] [17] [18] [19]. Coagulation and sedimentation processes are used to reduce drinking water turbidity. Following the removal of physical contaminants, microorganisms, including those found in fecal matter, such as Campylobacter ssp., Cryptosporidium parvum, rotavirus, Legionella ssp., cryptosporidium, E. coli, etc., that can be present in the water source, are eliminated by us- 
ing hydrogen peroxide and chlorine [20]. These water-borne pathogens can cause gastrointestinal illnesses, ranging from mild to severe [21] [22] [23]. Between 2013-2014 in the United States, water-borne pathogens were responsible for 13 deaths, 124 individuals' hospitalizations, and 1006 illnesses, collectively [24]. According to a study, water-borne disease outbreaks occurred in cluster and were more common in western Europe, among other countries [25]. It is estimated by the WHO that two billion people still use water contaminated with fecal matter [17]. To reduce water-borne pathogenic outbreaks, water treatment facilities use chlorine or chlorine dioxide to disinfect water in many countries across the globe, especially countries that have adequate water infrastructure. However, chlorine residues and by-products, such as trihalomethanes, have been associated with various types of cancers and fertility problems [26] [27] [28] [29]. There are many factors that dictate the level of trihalomethanes present in the drinking water, such as the quality of raw water, $\mathrm{pH}$ of water and chlorine residuals [30] [31] [32].

The advancement of infrastructure in the developed world, and the use of metals in buildings and for water transport, has further exasperated the challenge of providing high quality drinking water, as heavy metals, such as copper and lead, used in household plumbing, can leach into the drinking water. Heavy metals are monitored strictly by water agencies around the developed world, as seen in Table 1. Heavy metals can have many adverse effects especially on the development and cognition of children. Studies indicate that low levels of lead can impair normal cognition, and increase behavioral and learning disorders [33] [34] [35]. Hence, adequate measures are required to ensure that drinking water does not exceed the mandated limits as set forth by each country's water management agency (Table 1). This research aims to compare and evaluate drinking water quality and factors impacting such quality among developed countries, leading to possible recommendation for improved potable water quality for other countries.

\section{Materials and Methods}

For the data collection phase, secondary water quality data was collected for each country's capital city for the year 2019 [36]-[54]. Additional data, not published in the yearly water safety report, was obtained from each city's water service office via electronic communication with environmental agencies corresponding to each country. Numerical data was prepared for descriptive statistical analysis. Histograms were utilized to demonstrate lead, copper, turbidity, chlorine levels, total trihalomethane levels, $\mathrm{pH}$, and total coliform levels in different countries around the world. Each city's drinking water source was obtained from the water department for each country's capital city. In addition, raw data was further analyzed by the Statistical Analysis System (SAS) software (SAS Institute, Cary, NC) at type 1 error level, utilizing the Analysis of Variance (ANOVA) test. Tukey's grouping test was utilized to determine the variation among chlorine resi- 
dual levels in drinking water among different countries. Statistically significant variations, obtained from Tukey's test, are denoted by an asterisk $\left(^{*}\right)$. To compare the contaminant levels among different income groups, Tukey's test was utilized to examine statistical significance among different means [55]. Cities with similar means in their chlorine levels were labelled with the letter "A", while those with significant statistical difference were labelled with other letters ("B" and "C").

\section{Results and Discussion}

\subsection{Chemical Contaminants}

Examination of heavy metal levels in the tap water in the capital cities of Australia, Canada, Germany, Iceland, Ireland, New Zealand, Qatar, Singapore, the United Arab Emirates, the United Kingdom, and the United States, showed that copper and lead levels were well below the standards set forth by the World Health Organization (WHO). The United Arab Emirates demonstrated the highest levels of both copper and lead (Figure 2), which were attributed to electroplating, mining, paint, gasoline batteries, as well as piping and plumbing materials [56]. Additionally, Canada demonstrated high copper levels, Qatar and Germany demonstrated high lead levels.

Analysis of chlorine and chlorination by-products showed that the United States, Singapore, and Canada had the highest levels of chlorine in their drinking water (Figure 3). Although many countries require chlorine levels to be below 5 $\mathrm{mg} / \mathrm{L}$, the United States and the United Arab Emirates specifically require chlorine levels to be above $0.2 \mathrm{mg} / \mathrm{L}$. This minimal level of chlorination is implemented to mitigate the potential health risks associated with drinking raw water.

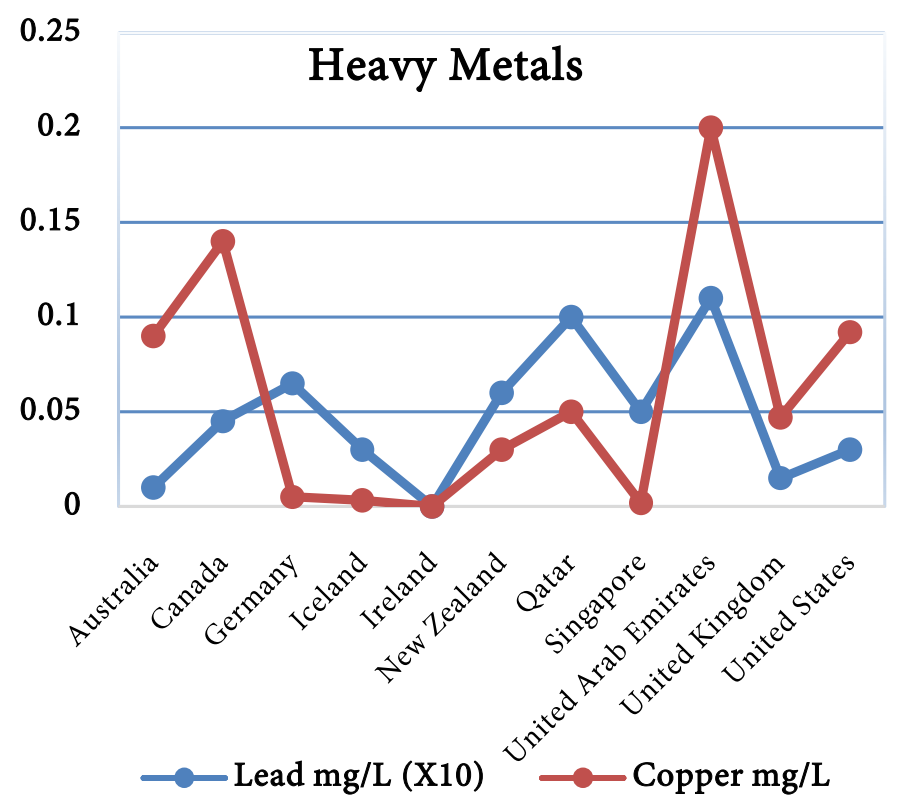

Figure 2. Heavy metal analysis in drinking water among developed countries. The United Arab Emirates demonstrated the highest levels of copper and lead in drinking water. 


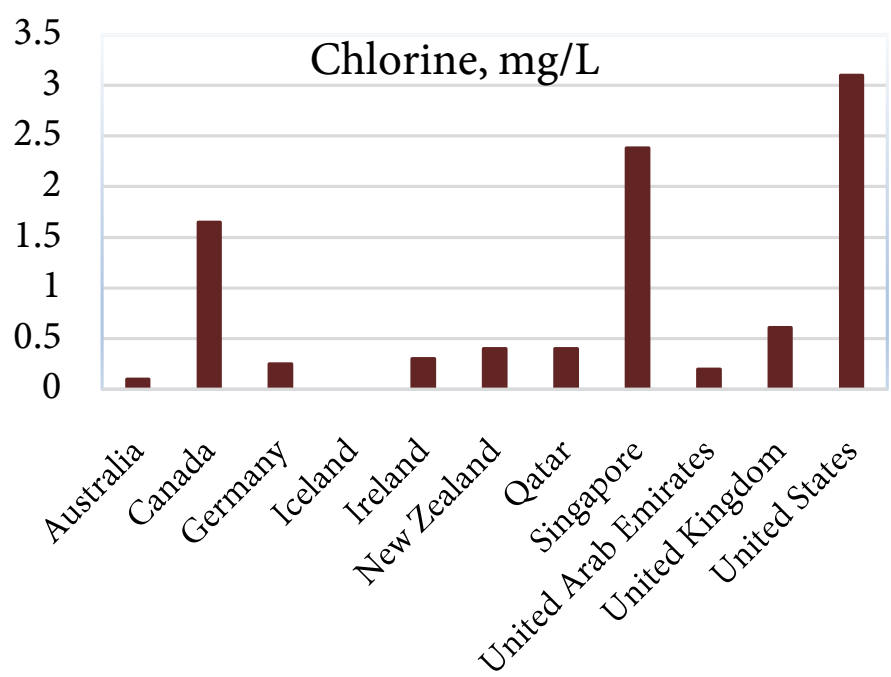

Figure 3. Residual chlorine levels $(\mathrm{mg} / \mathrm{L})$ in drinking water among developed countries. The United States, Singapore, and Canada demonstrated the highest levels of chlorine. Icelandic water had zero chlorine levels, followed by Australia, the United Arab Emirates, and Germany.

Furthermore, Iceland did not report chlorine in their drinking water, due to the pristine nature of their raw water and therefore the lack of the need to chlorinate. Although chlorination is necessary to reduce water-borne illnesses, chlorine residues can react with humic and fulvic acids, naturally present in raw water, and produce bromoform, chloroform, dibromochloromethane, and bromodichloromethane, collectively known as total trihalomethanes (TTHMs). Total trihalomethane levels were found to be the lowest in the United Kingdom and Singapore, while Qatar and Iceland demonstrated the highest levels (Figure 4). Total trihalomethanes were not reported for Ireland and the United Arab Emirates. Upon further investigation, the violation in Ireland was attributed to the presence of peat soil and agricultural land surrounding the catchment, which increased humic acid concentration, leading to the eventual reaction with disinfectant and the increased levels of total trihalomethanes [57].

To determine the significant mean difference between the chlorine levels $(\mathrm{mg} / \mathrm{L})$ among different countries, statistical analysis (SAS Institute, Cary, NC) at type 1 error level utilizing ANOVA ( $\mathrm{P}<0.05$, Tukey-adjusted ANOVA) was utilized. This analysis revealed that the United States, Canada, and Singapore had significantly higher chlorine levels in their drinking water, compared to the other developed countries (Figure 5).

\subsection{Physical Contaminants}

The levels of turbidity, an important physical contaminant, were analyzed in various countries. The analysis revealed that the United Arab Emirates had the most turbid water, followed by Australia, New Zealand, and Qatar. On the other hand, Canada, Ireland, Singapore, the United Kingdom, and the United States demonstrated the least amount of turbidity in their drinking water (Figure 6). 


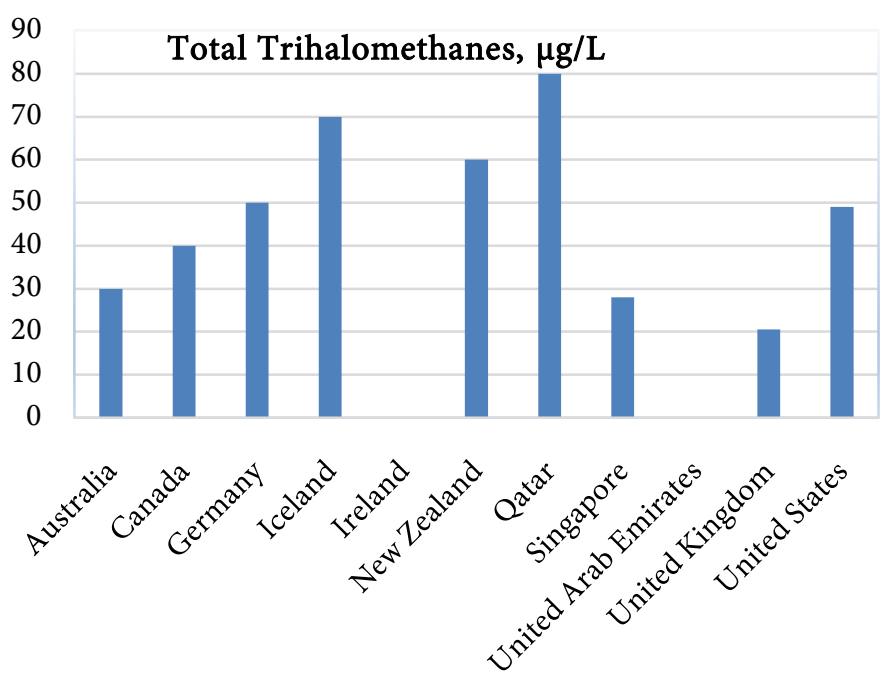

Figure 4. Total trihalomethane levels (mg/L) for developed countries. Qatar and Iceland demonstrated the highest levels of total trihalomethanes (TTHMs), while the United Kingdom and Singapore demonstrated the lowest levels of trihalomethanes in their drinking water. The United Arab Emirates and Ireland failed to report TTHMs levels.

\section{Chlorine levels $(\mathrm{mg} / \mathrm{L})$ in drinking water among different countries}

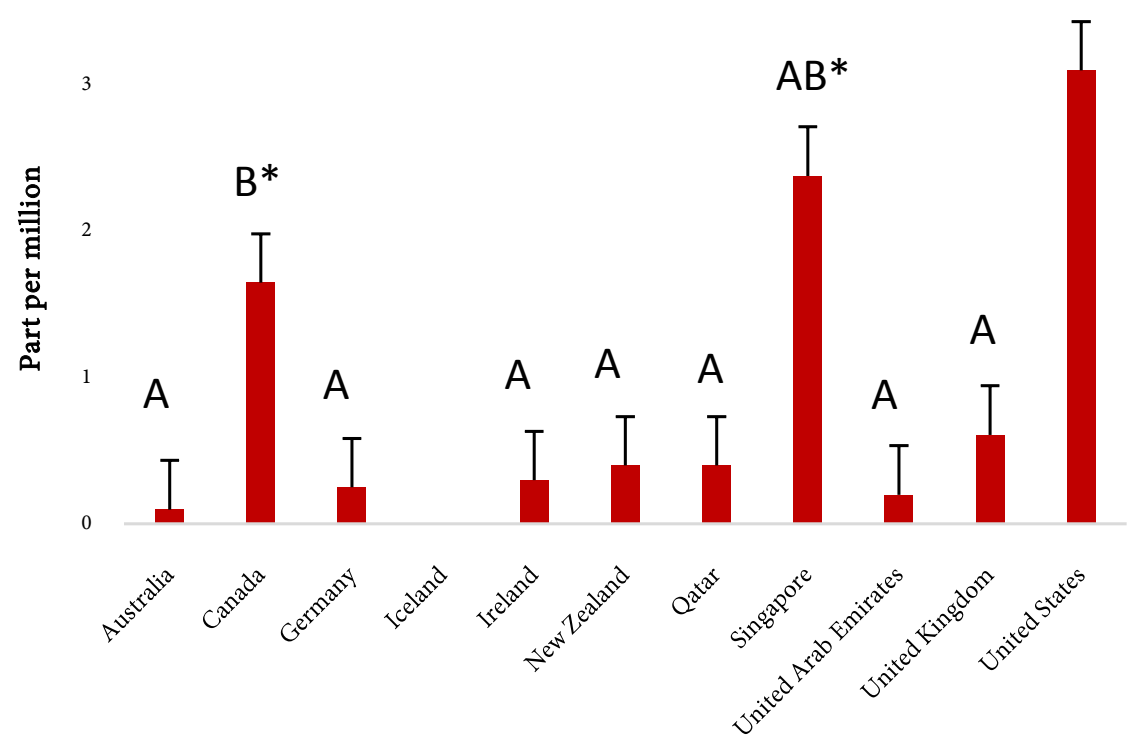

Figure 5. Statistical analysis to determine the significant mean difference between chlorine levels (mg/L) among different countries. ANOVA statistical analyses $(\mathrm{P}<0.05$, Tukey-adjusted ANOVA) indicated significant differences in chlorine levels in drinking water. The statistical variation among the chlorine levels in different countries is indicated by $\mathrm{A}, \mathrm{B}$, and $\mathrm{C}$, and the statistical significance is denoted by an asterisk $\left(^{*}\right)$.

Further investigation revealed that Qatar and the United Arab Emirates obtain their water from the Persian Gulf (Table 2) and their drinking water goes through a desalination process, rather than the traditional coagulation, sedimentation, and flocculation processes employed by countries using surface water. Hence, the lack of coagulation processes in Qatar and the United Arab Emirates could be 


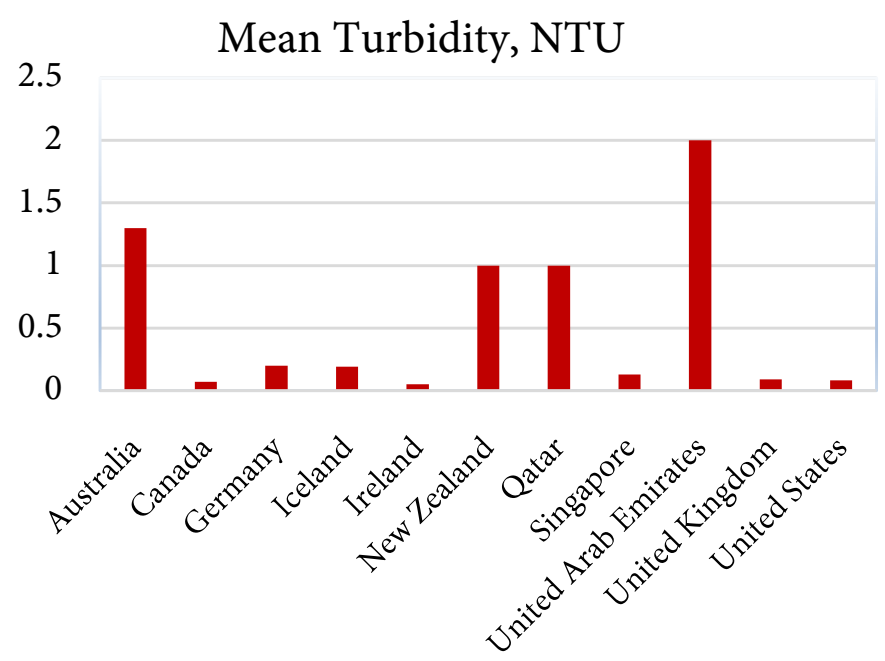

Figure 6. Mean turbidity (NTU) for developed countries. The United Arab Emirates had the most turbid drinking water, while the United States, the United Kingdom, Ireland, Canada, and Singapore had the least turbid water.

the leading factor in the elevated turbidity levels in their water. $\mathrm{pH}$ levels were also analyzed in the drinking water of various countries. Canada seemed to have the most alkaline water ( $\mathrm{pH}$ greater than 7 ), while New Zealand had the most neutral water $(\mathrm{pH} \sim 7)$, as shown in Figure 7. No country demonstrated acidic water ( $\mathrm{pH}$ below 7$)$.

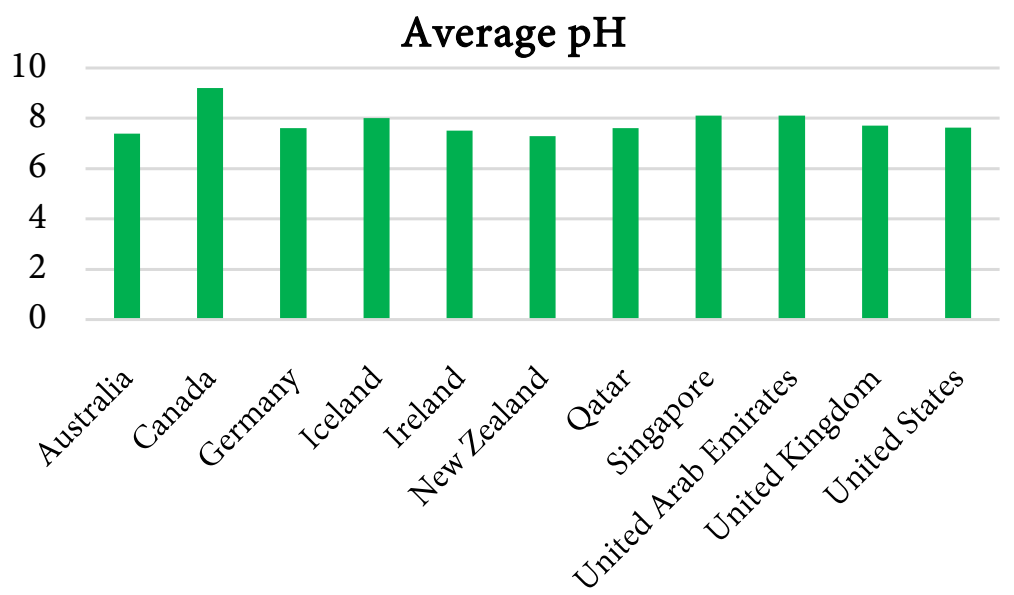

Figure 7. Average drinking water $\mathrm{pH}$ among developed countries. Drinking water in Canada, Iceland, Singapore, and the United Arab Emirates was more alkaline than in other countries.

\subsection{Biological Contaminants}

The highest allowable levels of total coliform in the drinking water of various countries are regulated at less than 1 colony-forming unit (CFU) per $100 \mathrm{~mL}$ of sample. In many countries, water samples are obtained periodically throughout the year and are analyzed to ensure public safety and prevent waterborne diseases. If violations are observed, "boil water" notices are sent to consumers to en- 
sure public health and mitigate illnesses induced by pathogens. Canada, New Zealand, and the United States had the highest levels of total coliform in their drinking water, while Germany, Ireland, the United Arab Emirates, and the United Kingdom had the lowest coliform levels (Figure 8). The higher observed levels of total coliform are attributed to the number of pathogens present in the water sources, as indicated in Table 2 , and the amount of chlorine used during the disinfection process. In general, the amount of total coliform remained below the levels mandated by the regulatory agencies of various countries.

\section{Coliform, cfu/100 mL}

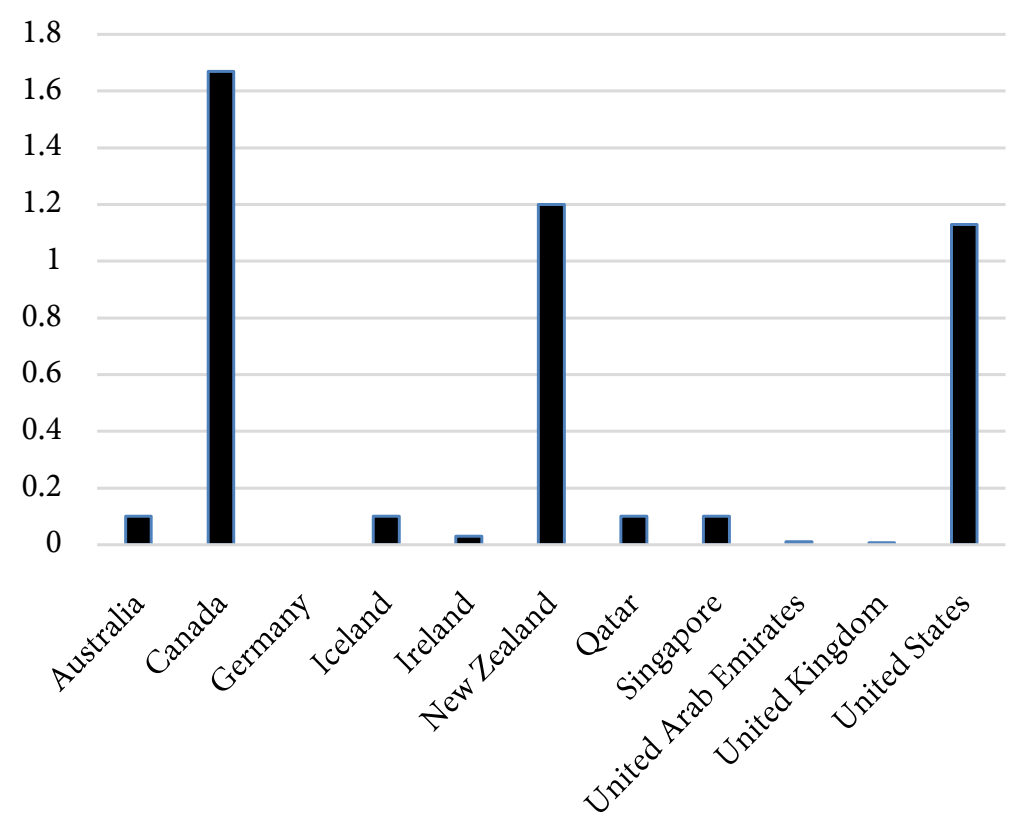

Figure 8. Total coliform levels $(\mathrm{cfu} / 100 \mathrm{~mL})$ in drinking water among developed countries. Canada, New Zealand, and the United States demonstrated the highest coliform levels.

\section{Conclusion}

Potable water is a necessity for the health and wellbeing of the general populace and should not be a source for health risks. As the civilized world has advanced, many techniques have been developed to reduce water-borne illness and mortality rates. However, new challenges have developed, as a result of increased population, industrial activities, and recreational activities. The current challenges are a result of architectural advancement, where paint and building plumping are a direct source of increased heavy metal levels in drinking water. In addition, although chlorination has improved water quality and eliminated water-borne pathogens, it has also increased total trihalomethane levels in the drinking water, which have been associated with cancers and reproductive anomalies. Qualitative measures utilized in this study further demonstrate the levels of contaminants present in the developed countries and raise the urgency to implement measures to reduce the levels of contaminants present in drinking water that can 
have lasting and long-term effects. Furthermore, a country's water source plays little role in the quality of drinking water, as groundwater and surface water are both susceptible to being contaminated. While surface water is more likely to be contaminated by human activity, groundwater can also be compromised by mining, poor waste management and agricultural runoff. Hence, regardless of the water source, water quality can be improved during the treatment process.

\section{Conflicts of Interest}

The authors declare no conflicts of interest regarding the publication of this paper.

\section{References}

[1] Leal, J.L. (1909) The Sterilization Plant of the New Jersey City Water Supply Company at Boonton, NJ. Proceedings American Water Works Association, 100-109.

[2] Hazen, A. (1916) Clean Water and How to Get It. Wiley, Hoboken, 102.

[3] Leoni, V., Fabiani, L., Marinelli, G., Puccetti, G., Tasitani, G.F., De Carolis, A., Vascia, N., Morini, A., Aleandri, V., Pozzi, V., Cappa, F. and Barbati, D. (1989) PCB and Other Organochlorine Compounds in Blood of Women with or without Miscarriage: A Hypothesis of Correlation. Ecotoxicology and Environmental Safety, 17, 1-11. https://doi.org/10.1016/0147-6513(89)90002-X

[4] Pathak, R., Mustafa, M., Ahmed, R.S., Tripathi, A.K., Guleria, K. and Banerjee, B.D. (2009) Association between Recurrent Miscarriages and Organochlorine Pesticide Levels. Clinical Biochemistry, 43, 131-135. https://doi.org/10.1016/j.clinbiochem.2009.09.019

[5] Den Hond, D., Schoeters, G., Koppen, G., Van Larebeke, N., Nelen, V., Bruckers, L. and D'Hooghe, T. (2006) Relationship between PCBs, Dioxins, Chlorinated Pesticides, and Fertility Problems in Young Women. Epidemiology, 17, S193. https://doi.org/10.1097/00001648-200611001-00489

[6] International Agency for Research on Cancer (1990) Chlorinated Drinking-Water, Chlorination By-Products, Some Other Halogenated Compounds, Cobalt Compounds. IARC Working Group on the Evaluation of Carcinogenic Risks to Humans: Chlorinated Drinking-Water, Lyon.

http://bases.bireme.br/cgi-bin/wxislind.exe/iah/online/?IsisScript=iah/iah.xis\&src=g oogle\&base $=$ WHOLIS\&lang $=$ p\&nextAction $=\operatorname{lnk\& \text {exprSearch}=9283212525\& \text {indexS}}$ earch=ID

[7] Flaten, T.P. (1992) Chlorination of Drinking Water and Cancer Incidence in Norway. International Journal of Epidemiology, 21, 6-15.

https://doi.org/10.1093/ije/21.1.6

[8] Morris, R.D., Audet, A.M., Angelillo, I.F., Chalmers, T.C. and Mosteller, F. (1992) Chlorination, Chlorination By-Products, and Cancer: A Meta-Analysis. American Journal of Public Health Association, 82, 955-963. https://doi.org/10.2105/AJPH.82.7.955

[9] Environmental Protection Agency (EPA) (1970) Reorganization Plan No. 3 of 1970. https://archive.epa.gov/epa/aboutepa/reorganization-plan-no-3-1970.html

[10] Environmental Protection Agency (EPA) (2018) Ground Water and Drinking Water: National Primary Drinking Water Regulations.

https://www.epa.gov/ground-water-and-drinking-water/national-primary-drinking 
-water-regulations\#Microorganisms

[11] Gulf News (2015).

https://gulfnews.com/uae/environment/abu-dhabi-groundwater-to-run-out-in-50-y ears- 1.1448910

[12] SDWA (2017) Background on Drinking Water Standards in the Safe Drinking Water Act (SDWA). US Environmental Protection Agency (EPA), Washington DC. https://www.epa.gov/sdwa/background-drinking-water-standards-safe-drinking-wa ter-act-sdwa

[13] Dieter, C.A. and Maupin, M.A. (2017) Public Supply and Domestic Water Use in the United States, 2015. US Geological Survey Open-File Report 2017-1131, 6 p. https://doi.org/10.3133/ofr20171131

[14] Karim, K., Guha, S. and Beni, R. (2020) Comparative Analysis of Water Quality Disparities in the United States in Relation to Heavy Metals and Biological Contaminants. Water, 12, 967. https://doi.org/10.3390/w12040967

[15] Lenntech (2019) EU’s Drinking Water Standards. https://www.lenntech.com/applications/drinking/standards/eu-s-drinking-water-sta ndards.htm

[16] World Health Organization (2017) Water Quality and Health-Review of Turbidity: Information for Regulators and Waste Water Supplies.

https://www.who.int/water_sanitation_health/publications/turbidity-information-2 00217.pdf

[17] World Health Organization (2019) Drinking-Water. https://www.who.int/en/news-room/fact-sheets/detail/drinking-water

[18] Environmental Protection Agency (EPA) (2018) Ground Water and Drinking Water: National Primary Drinking Water Regulations.

https://www.epa.gov/ground-water-and-drinking-water/national-primary-drinking -water-regulations\#Microorganisms

[19] United States EPA (2018) 2018 Edition of the Drinking Water Standards and Health Advisories Tables.

https://www.epa.gov/sites/production/files/2018-03/documents/dwtable2018.pdf

[20] Szewzyk, U., Szewzyk, R., Manz, W. and Schleifer, K.-H. (2000) Microbiological Safety of Drinking Water. Annual Review of Microbiology, 54, 81-127. https://doi.org/10.1146/annurev.micro.54.1.81

[21] Hass, C., Rose, J. and Gerba, C. (1999) Quantitative Microbial Risk Assessment. John Wiley \& Sons, Inc., Hoboken, 1-5.

[22] Sponseller, J.K., Griffiths, J.K. and Tzipori, S. (2014) The Evolution of Respiratory Cryptosporidiosis: Evidence for Transmission by Inhalation. Clinical Microbiology Reviews, 27, 575-586. https://doi.org/10.1128/CMR.00115-13

[23] Despommier D.D., Griffin, D.O., Gwadz, R.W., Hotez, P.J. and Knirsch, C.A. (2019) Giardia Lamblia. Parasitic Diseases. 7th Edition, Parasites without Borders, 11-20.

[24] Benedict, K., Reses, H., Vigar, M., Roth, D., Roberts, V., Mattioli, M., Cooley, L., Hilborn, E., Wade, T., Fullerton, K., Yoder, J. and Hill, V. (2017) Surveillance for Waterborne Disease Outbreaks Associated with Drinking Water-United States, 2013-2014. Morbidity and Mortality Weekly Report (MMWR), 66, 1216-1221. https://doi.org/10.15585/mmwr.mm6644a3

[25] Yang, K., LeJeune, J., Alsdorf, D., Lu, B., Shum, C. and Liang, S. (2012) Global Distribution of Outbreaks of Water-Associated Infectious Diseases. PLoS Neglected Tropical Diseases, 6, e1483. https://doi.org/10.1371/journal.pntd.0001483 
[26] Villanueva, C.M., Gracia-Lavedan, E., Bosetti, C., Righi, E., Molina, A.J., Martin, V., Boldo, E., Aragones, N., Perez-Gomez, B., Pollan, M., Acebo, I.G., Altzibar, J.M., Zabala, A.J., Ardanaz, E., Peiro, R., Tardon, A., Chirlaque, M.A., Tavani, A., Polesel, J., Serraino, D., Pisa, F., Castano-Vinyals, G., Espinosa, A., Espejo-Herrera, N., Palau, M., Moreno, V., La Vecchia, C., Aggazzotti, G., Nieuwenhuijsen, M.J. and Kogevinas, M. (2017) Colorectal Cancer and Long-Term Exposure to Trihalomethanes in Drinking Water: A Multicenter Case-Control Study in Spain and Italy. Environmental Health Perspectives, 125, 56-65. https://doi.org/10.1289/EHP155

[27] Klaasen, C.D. (2019) Casarett and Doull's Toxicology: The Basic Science of Poisons. 9th Edition, McGraw-Hill Education, New York.

[28] Waller, K., Swan, S.H., DeLorenze, G. and Hopkins, B. (1998) Trihalomethanes in Drinking Water and Spontaneous Abortion. Epidemiology, 9, 134-140.

https://doi.org/10.1097/00001648-199803000-00006

[29] Grazuleviciene, R., Nieuwenhuijsen, M.J., Vencloviene, J., Kostopoulou-Karadanelli, M., Krasner, S.W., Danileviciute, A., Balcius, G. and Kapustinskiene, V. (2011) Individual Exposures to Drinking Water Trihalomethanes, Low Birth Weight and Small for Gestational Age Risk: A Prospective Kaunas Cohort Study. Environmental Health, 10, 1-11. https://doi.org/10.1186/1476-069X-10-32

[30] Levin, R.B., Epstein, P.R., Harrington, W., Olson, E. and Eric, G. (2002) U.S. Drinking Water Challenges in the Twenty-First Century. Environmental Health Perspective, 110, 43-52. https://doi.org/10.1289/ehp.02110s143

[31] Dubrovsky N.M., Burow K.R., Clark G.M., Gronberg, J.M., Hamilton, P.A., Hitt, K.J., Mueller, D.K., Munn, M.D., Nolan, B.T., Puckett, L.J., Rupert, M.G., Short, T.M., Spahr, N.E., Sprague, L.A. and Wilber, W.G. (2010). The Quality of Our Nation's Waters-Nutrients in the Nation's Streams and Groundwater, 1992-2004. US Geological Survey, Reston. http://pubs.usgs.gov/circ/1350/ https://doi.org/10.3133/cir1350

[32] Adin, A., Katzhendler, J., Alkaslassy, D. and Rav-Acha, C. (1991) Trihalomethane Formation in Chlorinated Drinking Water: A Kinetic Model. Water Research, 25, 797-805. https://doi.org/10.1016/0043-1354(91)90159-N

[33] Yousef, S., Eapen, V., Zoubeidi, T., Kosanovic, M., Mabrouk, A. and Ademnd, A. (2013) Learning Disorder and Blood Concentration of Heavy Metals in the United Arab Emirates. Asian Journal of Psychiatry, 6, 394-400. https://doi.org/10.1016/j.ajp.2013.04.005

[34] Nigg, J., Knottnerus, M., Martel, M., Nikolas, M., Cavanagh, K., Karmaus, W. and Rappley, M. (2007) Low Blood Lead Levels Associated with Clinically Diagnosed Attention-Deficit/Hyperactivity Disorder and Mediated by Weak Cognitive Control. Biological Psychiatry, 63, 325-331. https://doi.org/10.1016/j.biopsych.2007.07.013

[35] Feldman, R. and White, R. (1992) Lead Neurotoxicity and Disorders of Learning. Journal of Child Neurology, 7, 354-359. https://doi.org/10.1177/088307389200700404

[36] Thames Water Utility Limited (2019) Water Quality Report-2020. http://twmediadevcdn.azureedge.net/waterquality/WQ\%20Report_Z0350_St\%20Jo hns\%20Wood\%20\&\%20Mayfair.pdf

[37] Ottawa (2019) 2019 Annual Report on Drinking Water Quality. https://documents.ottawa.ca/sites/documents/files/2019_Annual\%20Report_Lemie ux\%20Island.pdf

[38] European Commission (2018) Proposal for a Directive of the European Parliament 
and of the Council on the Quality of Water Intended for Human Consumption. https://ec.europa.eu/environment/water/water-drink/pdf/revised_drinking_water_d irective.pdf

[39] Reykjavik Grapevine (2014) Something in the Water. https:/grapevine.is/mag/articles/2014/07/01/something-in-the-water/

[40] Gunnarsdottir, M.J., Gardarssona, S.M., St. Jonssonb, G. and Bartramc, J. (2016) Chemical Quality and Regulatory Compliance of Drinking Water in Iceland. International Journal of Hygiene and Environmental Health, 219, 724-733 https://doi.org/10.1016/j.ijheh.2016.09.011

[41] https://opinvisindi.is/bitstream/handle/20.500.11815/187/Post $\% 20$ print $\% 20-\% 20 \mathrm{Ch}$ emical\%20quality $\% 20$ and $\% 20$ regulatory $\% 20$ compliance $\% 20$ of $\% 20$ drinking $\% 20$ water $\% 2$ 0in\%20Iceland\%20-\%20post $\% 20$ print.pdf?sequence $=1$

[42] Berliner Wasserbetriebe (2020) Tap Water-Always Fresh and Available. https://www.bwb.de/content/en/mobile/2136.php

[43] Berliner Wasserbetriebe (2019) Analysendaten der Wasserwerke. https://www.bwb.de/de/assets/downloads/analysewerte-wasserwerke.pdf

[44] Climate Change Post (2020) Fresh Water Resources: Iceland. https://www.climatechangepost.com/iceland/fresh-water-resources/

[45] DC Water (2018) 2018 Drinking Water Quality Report. https://www.dcwater.com/sites/default/files/documents/2018_dcwater_water_qualit y_report.pdf

[46] Qatar General Electricity and Water Corporation (2009) Drinking Water Quality in Qatar.

https://www.km.com.qa/MediaCenter/Publications/finalengbook.pdf

[47] Qatar General Electricity and Water Corporation (2014) Overview on: KAHRAMAA Drinking Water Quality Requirements.

https://www.km.com.qa/MediaCenter/Publications/KAHRAMAA\%20Drinking\%20 Water\%20Quality\%20Requirment.pdf

[48] Board of Health (1984) Drinking Water Standards for New Zealand. https://www.moh.govt.nz/NoteBook/nbbooks.nsf/0/C1CDCCCA9F9C74404C2565 D700186DCB/\$file/drinking\%20water\%20standards\%20for\%20nz.pdf

[49] PUB (2019) Singapore Drinking Water Quality. https://www.pub.gov.sg/Documents/Singapore_Drinking_Water_Quality.pdf

[50] RSB for Electricity \& Water (2019) Water Quality Regulations. https://www.rsbdubai.gov.ae/wp-content/uploads/2019/09/RSB-Water-Quality-Reg ulations-1.0.pdf

[51] Sydney Water (2020) Water Analysis. https://www.sydneywater.com.au/SW/water-the-environment/how-we-manage-syd ney-s-water/safe-drinking-water/water-analysis/index.htm

[52] UISCE Eireann: Irish Water (2020) Summary of the Drinking Water Quality Results for Your Water Supply Zone (WSZ).

https://www.water.ie/water-supply/water-quality/results/summary/

[53] Wellington Water (2019) Chemical Analysis-Te Marua. https://www.wellingtonwater.co.nz/your-water/drinking-water/how-is-it-treated/w hats-in-your-water/chemical-analysis-te-marua/

[54] Borgen Magazine (2017) Water Quality in Iceland: Soft and Pure. https://www.borgenmagazine.com/water-quality-iceland/ 
[55] Lowry, R. (2007) One-Way Analysis of Variance for Independent Samples. https://web.archive.org/web/20081017161620/http://faculty.vassar.edu/lowry/ch14p t2.html

[56] Al Rashdi, S., Arabi, A.A., Howari, F.M. and Said, A. (2015) Distribution of heavy metal in the Coastal Area of Abu Dhabi in the United Arab Emirates. Marine Pollution Bulletin, 97, 494-498. https://doi.org/10.1016/j.marpolbul.2015.05.052

[57] O’Driscoll, C., Sheahan, J., Renou-Wilson, F., Croot, P., Pilla, F., Misstear, B. and Xiao, L.W. (2018) National Scale Assessment of Total Trihalomethanes in Irish Drinking Water. Journal of Environmental Management, 212, 131-141.

https://doi.org/10.1016/j.jenvman.2018.01.070 